\title{
Study on Soil and Water Conservation and Governance of Urban Inland Rivers: A Case Study of Nakau River Basin Governance
}

\author{
Yiyuan Zhang ${ }^{1}$, Dong $\mathrm{Li}^{1}$, Yan $\mathrm{Sun}^{2 *}$, Ronghua Tang ${ }^{1}$ and Yongxin Nong ${ }^{1}$ \\ ${ }^{1}$ Nanning Reconnaissance \& Designing Institute of Pearl River Water Resources Commission in Guangxi, Nanning, Guangxi, 530007, \\ China \\ ${ }^{2}$ Guangxi Hydraulic Research Institute, Nanning, Guangxi, 530023, China
}

\begin{abstract}
Taking the Nakau River Basin Governance Project as the research area, the problems existing in the Nakau River Basin, the key and difficult points of water and soil conservation management, and the measures and implementation effects of water and soil conservation in urban rivers are discussed. According to the characteristics of soil and water loss in the inland rivers of the city, an effective prevention and control measure system was proposed, which ultimately effectively prevented human-induced soil and water loss during the construction of the project, protected water and soil resources, guaranteed the safe operation of the main project, and maintained and improved the regional ecology surroundings.
\end{abstract}

\section{Foreword}

Since the reform and opening up, with the development of China's industrialization and urbanization, many urban rivers have experienced serious environmental problems. This is mainly due to the emphasis on flood prevention and drainage measures in the early treatment of urban inland rivers. Most of the treatment measures were hardening and canalization of river channels, which completely destroyed the river ecosystem. In recent years, most of the urban inland rivers have been shown to be dirty, smelly, and disorder[1-2]. The water ecological service function in the river channel has declined, the river landscape function has been lost, and the urban river has lost its natural ecological side[3-6]. With the rapid development of urbanization, people have paid more and more attention to the problems caused by urban rivers. Corresponding sponge river urban river treatment methods have been widely recognized at home and abroad; many cities are carrying out urban river management measures. Soil and water loss in the treatment of urban inland rivers has become increasingly prominent, and the control of soil and water conservation in urban rivers has become more and more important[7$10]$.

\section{Status and problems}

The Nakau River Basin is located in the main inland rivers of Nanning City, and it has a wide area. The damage of soil and water directly affects the Nakau River environment, river flooding, engineering safety, and river water quality. Most of the two sides of the river are "village in the city". The river is polluted seriously and the waterlogging is frequent. There are more than 60 straight drainage outlets along the river. After testing, the COD in the river was 70 to $177 \mathrm{mg} / \mathrm{L}, \mathrm{NH} 3-\mathrm{N}$ was 8 to $29 \mathrm{mg} / \mathrm{L}$, TN was 20 to $55 \mathrm{mg} / \mathrm{L}$, and the water was black and smelly[11]. The river is dirty and littered on both sides of the river. Construction waste soil encroaches on the river, which causes the river to be flooded. The construction scope is large, which occupate the original landforms and reduce the land productivity and soil corrosion resistance. Under the conditions, serious soil and water loss is easily caused, which directly affects the project construction scope and the production and life of the surrounding people. The amount of waste earthwork generated during the construction is large. If the waste earthwork is not effectively controlled, it will be directly discharged into the river. It will move in the form of suspended matter and displacer in the river. It will cause sedimentation and block the river, which will have a very adverse impact on the Nakau River and even the Minjiang River, and threaten the lives and property safety of the people. At the same time, when the sediment is washed down to the downstream power station, the service life of the water conservancy hub is reduced.

\section{Soil and water loss prediction}

According to field investigations, the main type of soil erosion in the project area is hydraulic erosion, and erosion is more common as surface erosion. During the construction of the project, if the necessary soil and water conservation measures are not taken, the project will produce a large amount of soil and water loss. The summary table for the prediction of soil and water loss in each area of the project area is shown in Table 1 and

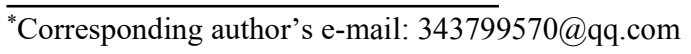


Figure 1. The current amount of soil and water loss is predicted according to the analog method. The analog project is the main stadium project of Guangxi Sports Center. It can be seen from Table 1 that the total amount of soil loss in the river improvement project area is $620.17 \mathrm{t}$, and the newly added soil loss is 599.71t; the total soil loss in the landscape and sponge city demonstration area is $1505.69 \mathrm{t}$, and the newly added soil loss is 1315.28t; the total amount of soil loss in the sewage plant area is $193.51 \mathrm{t}$, and the newly added soil loss is $169.75 \mathrm{t}$; the total soil loss in the temporary soil filling area is 222.64t, and the newly added soil loss is $176.88 \mathrm{t}$; the total amount of soil loss in the construction production and living area is $35.15 \mathrm{t}$, and the newly added soil loss is $18.40 \mathrm{t}$.
According to the analysis of the prediction results of the amount of soil and water loss, the area with the largest amount of soil and water loss was the landscape and sponge city demonstration area, followed by the river improvement project area. The reason for the large amount of soil and water loss in the two areas is due to the larger surface disturbance area and longer disturbance time. The key areas for soil erosion control in this project are the landscape and sponge city demonstration area and river improvement project area. Because soil erosion in these areas has a large impact range, lasts a long time, and has a large amount of soil erosion, the corresponding damage to soil erosion may also be greater.

Table 1. Prediction of soil and water loss in different zone.

\begin{tabular}{|c|c|c|c|c|}
\hline \multirow{2}{*}{ Area } & \multicolumn{2}{|c|}{ Total soil erosion } & \multicolumn{2}{|c|}{ Increase in soil erosion } \\
\hline & Quantity(t) & proportion $(\%)$ & Quantity(t) & proportion $(\%)$ \\
\hline River improvement project area & 620.17 & 24.06 & 577.91 & 25.59 \\
\hline $\begin{array}{c}\text { Landscape and sponge city } \\
\text { demonstration area }\end{array}$ & 1505.69 & 58.42 & 1315.28 & 58.24 \\
\hline Sewage plant area & 193.51 & 7.51 & 169.75 & 7.52 \\
\hline Temporary soil filling area & 222.64 & 8.64 & 176.88 & 7.83 \\
\hline $\begin{array}{c}\text { Construction production } \\
\text { and living area }\end{array}$ & 35.15 & 1.36 & 18.40 & 0.81 \\
\hline Total & 2577.16 & 100.00 & 2258.22 & 100.00 \\
\hline
\end{tabular}

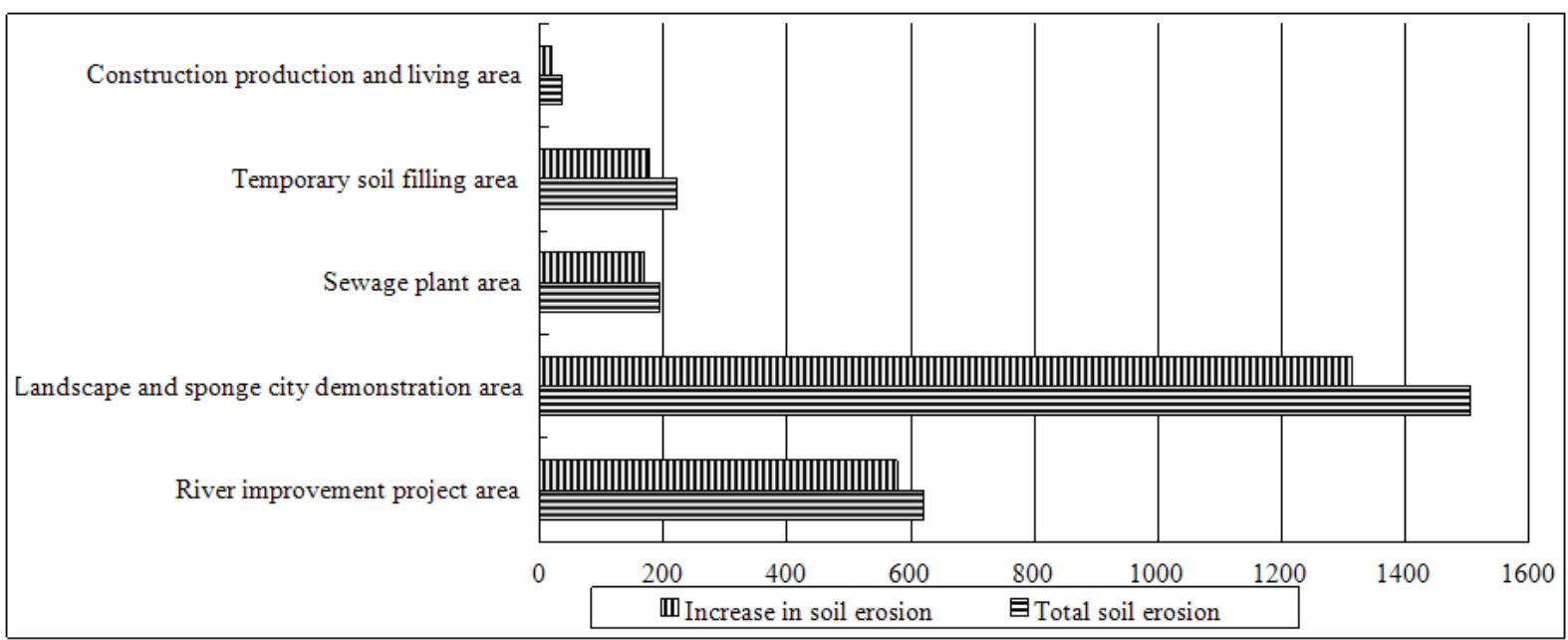

Figure 1. Comparison of soil and water loss in various area. Unit: t.

\section{$4 \quad$ Key and difficult points of soil and water conservation}

The Nakau River Basin covers a wide area, with a large amount of earth and stone. The waste slag is mainly stone, which is difficult to handle. The waste slag is about 1.763 million cubic meters. The sludge in the waste slag accounts for more than $16.62 \%$, which is difficult to transport and handle. The sludge contains heavy metals and other harmful substances which has an odor. It cannot be used for the filling of agricultural projects. Therefore, the engineering sludge is dried on both sides of the river and mixed with dry soil and transported to the waste slag digestion site. The river basin is located in the urban area, the amount of waste slag is large, and it is difficult to choose the transportation route and distance of the consumption site. During the treatment process, a large amount of abandoned slag and sludge are generated. The disposal method and fate of the excavated sludge are the key difficulties of the project.

\section{Control measures for soil and water conservation}

\subsection{Soil and water conservation engineering design}


River improvement project area: After excavation of the slope of the main project, large areas of bare steep slopes shall be temporarily covered with geotextiles before rainfall, and temporary soil drainage ditches and sedimentation ponds shall be set up at the top of high. When the riverside is filled with clay, temporary blocking measures will be set at the foot of the slope, temporary blocking will be set up for the backfill pile. Cofferdams will be removed at the end of the construction period, and ecological chain bricks will be used to protect the slopes. Aquatic plants will be planted in the waters.

Landscape and Sponge City Demonstration Area: Before excavation of the main project, the topsoil shall be stripped and piled up into the temporary soil pile-up area. Temporary drainage ditches and sedimentation tanks shall be built on both sides of the temporary soil pile-up area. Provision of temporary drainage and sedimentation measures at the edge of the red line without a municipal drainage ditch. In the later stage of construction, a grass planting ditch is arranged near the coastal walkway. The slope is protected by a threedimensional vegetation net. Part of the square and the sidewalk are permeable bricks. The above-ground parking spaces are ecological parking lots. Finally, the project area needs landscape greening. Cover the topsoil and site preparation in the areas where landscape greening is needed, and plant various landscape forests and grasses. After the top surface soil layer is excavated, it is stacked at the bottom of the stockpile, and then the material is excavated in the lower layer of the trench. In order to prevent the loss, straw bags are installed on the side far from the road, and the backfill soil temporarily stacked on both sides of the pipeline is temporarily covered with geotextile.

Sewage plant area: Before the construction of the sewage plant, the topsoil is stripped, and temporary drainage ditches and sedimentation tanks are built around it. After the construction is completed, the topsoil is rebuilt, the land is prepared, and the landscape is greened. Part of the hardened area on the site is permeable bricks, and the above-ground parking spaces are ecological parking lots. Rainwater outlets are installed on the hard squares and main roads to discharge rainwater into the municipal sewage pipe network system.

Temporary soil filling area: Before the temporary pile of topsoil, build temporary drainage ditches and sedimentation ponds around it, and then build a soil straw bag retaining wall. After the topsoil is completed, spread grass seeds or cover geotextiles on the top. Before the project is completed, the topsoil is returned to the relevant green area, and the straw bag retaining wall is removed.

Construction production and living area: Before construction, the construction production and living area shall be constructed with temporary drainage ditches and sedimentation ponds. Later, after the construction camp is demolished, the site will be cleared, and the site will be submitted to the main project for landscape greening.

\subsection{Soil and water conservation management}

The Nakau River Basin Governance Project implements rules and regulations such as the project legal person responsibility system, bidding system, construction supervision system, and contract management system. The system guarantees and regulates the successful completion of various projects, and lays the foundation for its use.

\section{Implementation effect and discussion of soil and water conservation}

The Nakau River Basin Governance Project was completed in December 2016. During the construction process, no serious soil erosion was found in the project. At present, the project is running well, and the prevention and control targets determined by the soil and water conservation plan have been reached. The soil and water conservation engineering measures in the project area are in place, and the soil and water conservation protection effect is obvious. The soil and water loss was effectively controlled during the construction period, and the generation of yellow mud water was basically eliminated. The soil and water conservation plants have selected suitable local tree species and grass species; the plant measures have adopted a variety of threedimensional greening modes such as grass-irrigation combination, tree-irrigation combination, and irrigationgrass combination. The soil and water conservation plant growth of the project is good, and the ecological environment has been significantly improved. These measures have prevented the occurrence of major water and soil loss disasters, and effectively controlled the water and soil loss in disturbed areas.

During the natural recovery period, relevant units carried out continuous inspection on the water quality monitoring section of the Nakau River, and the results showed that: the COD was $8-12 \mathrm{mg} / \mathrm{L}$, BOD5 was 0.8 $1.7 \mathrm{mg} / \mathrm{L}$, and NH3-N was $0.078-1.3 \mathrm{mg} / \mathrm{L}$, TP was 0.05 to $0.19 \mathrm{mg} / \mathrm{L}$, DO was 6.42 to $9 \mathrm{mg} / \mathrm{L}$, SS was 5 to 7 $\mathrm{mg} / \mathrm{L}$, TN was 8.04 to $9.05 \mathrm{mg} / \mathrm{L}$, and transparency was 55 to $163 \mathrm{~cm}$. All indicators meet the requirements of relevant standards in Nanning. After the treatment, the ecological restoration of the Nakau River Basin was realized. The aquatic plants in the river grew vigorously, and the aquatic animals such as fish, shrimp, and snails continued to reproduce. The ecological environment was completely improved. It become a public recreational wetland park and a new business card of Guangxi Zhuang Autonomous Region.

\section{References}

1. Xiang Y.J., Jiang H.D.,Zhou L.Z. (2010) Discussion on Design and Application of Inland River Ecological Landscape in Wenzhou. Soil and Water Conservation in China, 11: 57-59.

2. Feng BG.,(2014) Thoughts on Comprehensive Improvement and Development of Water 
Environment in Nanning.Modern property, 13: 169171.

3. Huang,O.(2019)Problems Existing in Comprehensive Treatment Project of Urban Water Environment and Solutions.WATER\&WASTEWATER ENGINEERING, 1: 1-3.

4. Liu D.M.,(2005)Talking about the methods of urban river management. Fujian Architecture \& Construction, 03:101-102.

5. Jing H.D., (2014)Investigation on Comprehensive Management of Urban Inland Rivers. China Homes, 02:301

6. Wang, X.Y.,(2007) Research on the Method of Comprehensive Urban River Management Based on Empirical Research. China Science and Technology Information, 14:191-192.

7. Huang,O.(2019)Problems Existing in Comprehensive Treatment Project of Urban Water Environment and Solutions.WATER\&WASTEWATER ENGINEERING, 1: 1-3.

8. Li H.,Cao Y.L.(2018)Analysis of Urban River Management Measures.Rural and ecological environment, 7: 125-126.

9. Liang,Q.Z.,Zhang,X.B.(2015)Problems of Urban Inland Rivers and Their Control Measures.Henan Water Resources and South-to-North Water Diversion, 14: 137-138.

10. Xu,Z.X.(2018)River pollution control technology.China Water Conservancy and Hydropower Press, Beijing.

11. Huang,M.S.,Cheng,Z.L.(2010)Urban river pollution control and ecological restoration. Science Press, Beijing. 